\title{
ANALISIS SEKTOR USAHA INFORMAL DI KOTA JAMBI
}

\section{Oleh :}

\author{
Ahmad Soleh ${ }^{1}$ \\ Dosen Tetap STIE Muhammadiyah Jambi ${ }^{1}$ \\ mas.soleh@yahoo.com \\ Prima Audia Daniel ${ }^{2}$ \\ Dosen Tetap STIE Muhammadiyah Jambi ${ }^{2}$ \\ primaaudia@ymail.com
}

\section{Ringkasan}

Dalam perekonomian sektor informal seringkali terlupakan namun mempunyai peran yang cukup besar dalam pembangunan. Dampak positif dari keberadaan sektor informal adalah terbukanya peluang usaha dan bekerja bagi masyarakat yang tidak tertampung dalam kegiatan ekonomi formal, dampak lainnya adalah aktivitas ekonomi menjadi meningkat karena sektor informal juga menjadi penjual sekaligus mengkonsumsi hasil-hasil produksi sektor formal. Ada dua tujuan utama dalam penelitian ini yaitu menganalisis faktor-faktor yang mempengaruhi pengembangan usaha sektor informal.

Hasil penelitian menunjukkan ada beberapa faktor yang mempengaruhi pengembangan usaha sektor informal diantaranya modal, jam kerja efektif dan jumlah pelanggan Modal $\left(X_{1}\right)$ yang dimiliki usaha sektor informal akan memberikan pengaruh terhadap kenaikan omzet penjualan sektor informal sebesar 0,965 persen. Jam kerja $\left(\left(X_{2}\right)\right.$ mendorong peningkatan omzet usaha sektor informal sebesar 0,241, jumlah pelanggan $\left(X_{4}\right)$ berpengaruh sebesar 0,124. Baik secara bersama-sama maupun secara parsial modal, jam kerja efektif dan jumlah pelanggan berpengaruh secara signifikan terhadap omzet usaha di Jambi.

Kata kunci : Pengembangan Usaha Sektor Informal.

\section{PENDAHULUAN}

Salah satu masalah penting yang sering dihadapi oleh negara berkembang adalah masalah penduduk dan ketimpangan pembangunan antar daerah, karena berkaitan erat dengan pembangunan, disamping sebagai subjek pembangunan juga sebagai objek pembangunan.

Di Indonesia sendiri setelah krisis ekonomi pembangunan mengalami pertumbuhan yang stagnasi dan lambat. Hal ini sudah barang tentu akan menimbulkan dampak terhadap meningkatnya pengangguran akibat banyaknya industri yang bangkrut dan terpaksa melakukan PHK besar-besaran. Hal ini dapat mendorong berkembangnya sektor informal, terutama di daerah perkotaan yang terdapat berbagai perusahaan industri.

Ibu kota Kabupaten/kota dalam Provinsi Jambi menjadi pusat produksi dan mendorong berkembangnya sektor informal. Sektor informal sendiri di samping memberikan dampak positif terhadap perkembangan perekonomian juga memberikan dampak terhadap kehidupan 
sosial masyarakat. Dampak positif dari keberadaan sektor informal adalah terbukanya peluang usaha dan bekerja bagi masyarakat yang tidak tertampung dalam kegiatan ekonomi formal, dampak lainnya adalah aktivitas ekonomi menjadi meningkat karena sektor informal juga menjadi penjual sekaligus mengkonsumsi hasil-hasil produksi sektor formal. Disamping dampak positif tentu juga ada dampak negatifnya, yaitu umumnya sektor informal tidak bekerja dalam sistem ekonomi yang terorganisir sehingga keberadaannya tidak memberikan kontribusi terhadap penerimaan pajak daerah, sektor informal dapat melahirkan kriminalitas karena mereka umumnya beroperasi di wilayah-wilayah terlarang dan membutuhkan perlindungan preman, di sisi lain sektor informal cenderung merusak keindahan kota karena tidak tertata rapi.

Sektor informal yang berkembang di daerah perkotaan juga memberikan dampak terhadap meningkatnya migran masuk ke daerah Perkotaan dan menjadi penyebab sulitnya penataan daerah perkotaan. Hal ini akan memberikan dampak terhadap semakin besarnya pengeluaran pemerintah dalam menyediakan sarana dan prasarana sosial serta keamanan mereka.

Namun demikian keberadaan sektor informal di daerah perkotaan di sisi lain memberikan manfaat yang besar terhadap penyerapan tenaga kerja. Mereka yang bekerja di sektor informal pada dasarnya adalah mereka yang tidak tertampung dalam lapangan pekerjaan sektor formal. Belum ada data yang pasti mengenai jumlah mereka yang bekerja di sektor informal, khususnya di daerah Jambi. Hal ini karena sulitnya dilakukan pendataan, terutama mengingat sektor informal sering berpindah tempat dan kadangkala musiman, seperti penjual buah-buahan, makanan, bangunan dan sebagainya. Untuk lebih jelasnya perkembangan sektor informal di Kota Jambi dapat dilihat pada tabel berikut ini :

Tabel 1.1. Perkembangan Sektor Informal di Kota Jambi Tahun 2013-2018:

\begin{tabular}{|c|c|c|c|c|}
\hline Tahun & $\begin{array}{c}\text { Jumlah Usaha } \\
\text { Sektor Informal }\end{array}$ & $\mathbf{( \% )}$ & $\begin{array}{c}\text { Volume usaha } \\
\text { (Perhari) }\end{array}$ & $\%$ \\
\hline 2013 & 243 & - & $305,815,500.00$ & - \\
2014 & 284 & 16,87 & $498,207,000.00$ & 62.91 \\
2015 & 297 & 4,58 & $655,027,560.00$ & 31.48 \\
2016 & 312 & 5,05 & $804,960,000.00$ & 22.89 \\
2017 & 334 & 7,05 & $921,308,940.00$ & 14.45 \\
2018 & 381 & 14,07 & $1.052 .665 .000,00$ & 14,26 \\
\hline Rata-rata & & 9,52 & & 29,198 \\
\hline
\end{tabular}

Sumber : Dinas Perindustrian dan Perdagangan Kota Jambi tahun 2018 
Dari tabel di atas tergambar bahwa jumlah usaha sektor informal selama periode 20132018 mengalami peningkatan sebesar 9,52 persen, perkembangan usaha sektor informal juga diikuti dengan peningkatan penyerapan tenaga kerja yang mengalami peningkatan rata-rata sebesar 50,94 persen, serta diikututi dengan peningkatan omzet penjualan perhari yang ratarata mengalami peningkatan sebesar 29,198 persen. Peningkatan ini jelas memberikan pengaruh yang positif terhadap peluang usaha dan dan bekerja bagi masyarakat di Kota Jambi. Adapun tujuan dari peneitian ini adalah untuk mengetahui faktor apa yang mempengaruhi pengembangan usaha sektor informal.

\section{METODOLOGI}

Dalam penelitian ini menggunkan metode analisis deskriptif kualitatif dan kuantitatif dengan menggunakan data primer dan data sekunder. Tehnik pengumpulan data dalam penelitian ini dibagi menjadi dua; untuk data primer dilakukan dengan cara angket, observasi dan wawancara dengan tehnik simple random sampling sementara untuk data sekunder dilakukan dengan cara studi literature.

Alat analisis yang digunakan dalam penelitian ini adalah regresi linier berganda dengan tujuan untuk melihat faktor faktor yang mempengaruhi keberhasilan usaha sektor informal, dengan model sebagai berikut:

$\mathrm{Y}_{\mathrm{t}}=\alpha_{0}+\alpha_{1} \mathrm{X}_{1}+\alpha_{2} \mathrm{X}_{2}+\alpha_{3} \mathrm{X}_{3}+\alpha_{4} \mathrm{X}_{4}+\varepsilon \mathrm{it}$

di mana :

$\mathrm{Y}=$ Omzet usaha dari sektor informal

$\mathrm{X}_{1} \quad=$ Modal usaha

$\mathrm{X}_{2} \quad=$ Jam kerja Efektif

$\mathrm{X}_{3} \quad=$ lokasi Usaha

$\mathrm{X}_{4} \quad=$ Jumah Pelanggan

$\alpha_{0}$ adalah konstanta; $\alpha_{1}, \alpha_{2}, \alpha_{3}, \alpha_{4}$, adalah parameter (koefisien Regresi); dan $\varepsilon$ adalah faktor gangguan (disturbance).

\section{HASIL PENELITIAN}

\section{Analisis Faktor-faktor yang mempengaruhi Pengembangan Usaha Sektor Informal Pengujian Model Regresi}

Dari hasil pengujian diperoleh persamaan regresi linear berganda menghasilkan persamaan regresi berganda sebagai berikut:

$\mathrm{Y}=-0,052+0,961 \mathrm{X}_{1}+0,028 \mathrm{X}_{2}+0,014 \mathrm{X}_{3}+0,041 \mathrm{X}_{4}$

$\mathrm{t}$ hit $=\quad(49,012 \quad(1,866) \quad(2,333) \quad(1,465)$ 
F hit $=645,711 \mathrm{~F}_{\text {Tabel }}=2,41 \quad \mathrm{R}^{2}=0,965 \quad \mathrm{~T}$ tabel $=1,761$

Berdasarkan hasil pengujian model regresi yang pertama ternyata terlihat nilai $\mathrm{R}^{2}$ sangat tinggi, sementara nilai $\mathrm{F}$ hitung juga sangat tinggi sehingga secara statistik menunjukkan pengaruh yang nyata terhadap variabel Y secara bersama-sama. Nilai t hitung juga menunjukkan angka yang lebih tinggi (kecuali untuk variabel $\mathrm{X}_{4}$, yaitu jumlah pelanggan). Sehingga model ini memiliki validitas yang tinggi untuk dapat diterjemahkan.

Hasil pengujian diatas menunjukkan bahwa peningkatan 1 persen modal akan mendorong peningkatan omzet penjualan usaha sektor informal di Kota Jambi sebesar 0,961\%. Sementara setiap terjadi peningkatan variabel jam kerja $\left(\mathrm{X}_{2}\right)$ sebesar 1 persen akan mendorong terjadinya peningkatan omzet usaha sektor informal mengalami peningkatan sebesar 0,028 persen. Di sisi lain lokasi usaha $\left(\mathrm{X}_{3}\right)$ yang strategis atau dekat dengan keramaian memiliki omzet penjualan yang lebih besar bila dibandingkan dengan lokasi usaha yang jauh dari keramaian dan setiap peningkatan jumlah pelanggan sebesar 1 persen akan meningkatan omzet penjualan sebesar 0,041 persen.

Hasil penelitian ini menunjukkan bahwa seluruh variabel berpengaruh positif terhadap peningkatan omzet penjualan. Masing-masing variabe baik secara bersama-sama maupun secara parsial memberikan kontribusi yang positif terhadap peningkatan omzet penjualan. Semakin besa penambahan variabel independent (bebas) maka akan semakin besar pula terjadi peningkatan omzet penjualan sektor informal di Kota Jambi.

\section{Pengujian Secara Simultan}

Koefisien determinasi dipergunakan untuk melihat berapa besar variabel Xi (modal, jam kerja, lokasi usaha dan jumlah pelanggan) dapat menjelaskan variasi nasik turunnya omzet penjualan di sektor informal. Dari hasil pengujian sebagaimana terlihat pada model ke ke dua regresi linear berganda (lampiran 4) diperoleh nilai koefsien determinasi sebesar 0,964. Hal ini memberikan gambaran bahwa 96,4 persen variasi naik turunnya omzet usaha sektor informal di Kota Jambi dijelaskan oleh modal, jam kerja dan jumlah pelanggan .

Uji F dipergunakan untuk melihat apakah secara bersama-sama variabel Xi (modal, tenaga kerja, lokasi usaha dan jumlah pelanggan) yang dimasukkan dalam model berpengaruh secara signifikan terhadap omzet penjualan pada sektor informal di Kota Jambi .

Dari hasil pengujian diperoleh nilai F hitung sebesar 645,711 Dengan tingkat keyakinan sebesar 95 persen $\alpha=0,05 \mathrm{df}=$ (96) (3) diperoleh nilai $\mathrm{F}$ tabel sebesar 2,265. Dengan demikian nilai $\mathrm{F}$ hitung $(645,711)$ lebih besar dari nilai $\mathrm{F}$ tabel $(2,265)$. Artinya secara 
bersama-sama variabel modal $\left(\mathrm{X}_{1}\right)$, jam kerja $\left(\mathrm{X}_{2}\right)$, lokasi usaha $\left(\mathrm{X}_{3}\right)$ dan jumlah pelanggan $\left(\mathrm{X}_{4}\right)$ memiliki pengaruh secara signifikan terhadap Omzet usaha sektor informal di Kota Jambi.

\section{Pengujian Secara Partial}

Uji $\mathrm{t}$ dipergunakan untuk melihat apakah secara parsial masing-masing variabel independent (modal, jam kerja. Lokasi usaha dan jumlah pelanggan) yang diteliti berpengaruh secara signifikan terhadap omzet usaha sektor informal di Kota Jambi

Dari hasil pengujian diperoleh nilai t hitung untuk variabel modal adalah sebesar 49,012, sementara nilai t tabel dengan tingkat keyakinan 95 persen diperoleh angka sebesar 1,761. Hal ini berarti bahwa nilai t hitung $(49,012)$ lebih besar dari nilai t tabel yang mengandung arti bahwa Ho ditolak artinya terdapat pengaruh yang signifikan antara modal usaha sektor informal dengan omzet usaha sektor informal di Kota Jambi dengan koefisien regresi 0.961 yang berarti setiap terjadi peningkatan modal sebesar 1 persen akan menyebabkan omzet usaha sektor informal di Kota Jambi mengalami peningkatan sebesar 0.961 persen

Modal sangat berperan penting bagi pekerja sektor informal, karena dengan ketersediaan modal berarti proses produksi atau berusaha mereka dapat berkesinambungan dari waktu ke waktu. Pekerja sektor informal yang memiliki modal sudah barang tentu dapat membeli peralatan kerja dan faktor produksi yang digunakan dalam proses produksi. Semakin tinggi modal yang dimiliki pekerja di sektor informal maka dengan sendirinya akan semakin besar omzet penjualannya.

Nilai thitung untuk variabel jam kerja diperoleh sebesar 1,866. sementara nilai t tabel dengan tingkat keyakinan 95 persen diperoleh sebesar 1,761. Hal ini berarti nilai t hitung $(1,866)$ lebih besar dari nilai $\mathrm{t}$ tabel $(1,761)$ yang berarti Ho ditolak artinya terdapat pengaruh yang signifikan antara jam kerja dengan omzet usaha sektor informal di Kota Jambi. Dengan nilai koefisien regresi sebesar 0,028 maka setiap terjadi peningkatan jumlah jam kerja sebesar 1 persen pada usaha usaha akan meningkatkan omzet usaha sektor informal di Kota Jambi sebesar 0,028 persen. Peningkatan jam kerja berdampak terhadap semakin banyaknya usaha atau proses produksi yang dapat dilakukan. Hal ini pada gilirannya akan semakin mendorong semakin meningkatnya jumlah omzet yang dapat terjual atau usaha yang dapat dilakukan oleh pekerja sektor informal.

Nilai thitung untuk variabel lokasi usaha adalah sebesar 2,333, sementara nilai t tabel dengan tingkat keyakinan 95 persen diperoleh sebesar 1,761. Hal ini memberikan gambaran 
bahwa lokasi usaha memiliki pengaruh yang signifikan terhadap omzet usaha sektor informal di Kota Jambi

Nilai t hitung untuk variabel jumlah pelanggan sektor informal diperoleh sebesar 1,465 sementara nilai t tabel pada tingkat keyakinan sebesar 95 persen diperoleh sebesar 1,761, hal ini berarti nilai t hitung $(1,465)$ lebih kecil dari nilai t tabel $(1,761)$. Dengan demikian maka Ho diterima dengan kata lain jumlah pelanggan tidak berpengaruh secara signifikan terhadap omzet usaha sektor informal di Kota Jambi. Hal ini juga terlihat dari nilai koefisien regresi sebesar 0,014 , yang berarti setiap terjadi peningkatan jumlah pelanggan usaha sektor informal sebesar 1 persen akan meningkatkan omzet usaha sektor informal sebesar 0,041 persen. Peningkatan jumlah pelanggan berarti semakin banyak pelanggan yang menggunakan produk atau jasa yang dihasilkan pekerja sektor informal. Hal ini pada gilirannya akan mendorong semakin meningkatnya omzet penjualan atau jasa yang ditawarkan kepada konsumen atau pengguna jasa.

\section{KESIMPULAN DAN SARAN}

\section{Kesimpulan}

Dari hasil penelitian dan pembahasan ada beberapa hal yang dapat disimpulkan, yaitu :

1. Faktor-faktor yang mempengaruhi pengembangan usaha sektor informal adalah modal, jam kerja efektif dan jumlah pelanggan Modal $\left(\mathrm{X}_{1}\right)$ yang dimiliki usaha sektor informal akan memberikan pengaruh terhadap kenaikan omzet penjualan sektor informal sebesar 0,965 persen. Jam kerja $\left(\left(\mathrm{X}_{2}\right)\right.$ mendorong peningkatan omzet usaha sektor informal sebesar 0,241 , jumlah pelanggan $\left(\mathrm{X}_{4}\right)$ berpengaruh sebesar 0,124. Baik secara bersama-sama maupun secara parsial modal, jam kerja efektif dan jumlah pelanggan berpengaruh secara signifikan terhadap omzet usaha di Jambi.

2. Hubungan keberhasilan pengembangan usaha sektor informal dengan penyerapan tenaga kerja adalah sangat kuat, yaitu sebesar 0,94754 .

\section{Saran}

Dari kesimpulan di atas maka ada beberapa saran yang dapat diberikan, yaitu:

1. Mengingat variabel modal adalah salah satau variabel yang berperan penting dalam pengembangan usaha sektor informal maka sebaiknya instansi terkait perlu memberikan bantuan permodalan dengan bunga rendah dan syarat yang mudah serta tanpa jaminan. Disamping itu juga perlu merekomendasikan kepada pihak perbankan atau pemilik modal untuk memberikan pinjaman kepada usaha sektor informal tanpa anggunan. 
2. Jam kerja memiliki pengaruh yang nyata terhadap perkembangan omzet usaha, oleh karena itu sebaiknya usahawan sektor informal perlu memanfaatkan waktunya secara intensif dan efisien.

3. Usahawan sektor informal perlu memberikan pelayanan yang baik kepada konsumen agar mereka tetap memiliki kepercayaan dan bersedia menjadi pelanggan.

4. Pengembangan sektor informal mempunyai kaitan dengan peningkatan daya serap tenaga kerja. Oleh karena itu perlu ditingkatkan mutu tenaga kerja salon usahawan sektor informal melalui pendidikan kewirausahaan sektor informal.

\section{DAFTAR PUSTAKA}

Haris, D. M. (2011). Strategi Pengembangan Usaha Sektor Informal dalam mendukung Pertumbuhan Ekonomi dan Penanggulangan Kemiskinan di Perkotaan.

Mahendra, S. (2018). Keterkaitan Modal Sosial Dengan Strategi Kelangsungan Usaha Pedagang Sektor Informal Di Kawasan Waduk Mulur: Studi Kasus Pada Pedagang Sektor Informal Di Kawasan Waduk Mulur Kelurahan Mulur Kecamatan Bendosari Kabupaten Sukoharjo. Jurnal Analisa Sosiologi, 4(2).

Rachbii, D, J., \& Abdul, H. (1994). Ekonomi Informal Perkotaan: Gejala inovesi gelombang Kedua. Jakarta: PT.Pustaka LP3ES.

Resalawati, A. (2011). Pengaruh perkembangan usaha kecil menengah terhadap pertumbuhan ekonomi pada sektor UKM di Indonesia.

Sinaga, A. (2013). Analisis Tenaga Kerja Sektor Informal Sebagai Katup Pengaman Masalah Tenaga Kerja di Kota Medan (Doctoral dissertation, UNIMED).

Soleh, A. (2017). Strategi Pengembangan Potensi Desa. Jurnal Sungkai, 5(1), 32-52.

Sugiyono. (2005). Memahami penelitian Kualitatif. Bandung Nusantara Press.

Tindaon, O., \& Yusuf, E. (2011). Analisis Penyerapan Tenaga Kerja Sektoral di Jawa Tengah (Pendekatan Demometrik) (Doctoral dissertation, UNIVERSITAS DIPONEGORO).

Wauran, P. (2012). Strategi Pemberdayaan Sektor Informal Perkotaan di Kota Manado. Jurnal Pembangunan Ekonomi Dan Keuangan Daerah, 7(1). 